\title{
Correspondence
}

To the Editors

\section{Paediatric COVID-19 and BCG vaccination: observation}

Sri Lanka Journal of Child Health, 2020; 49(4): 420

DOI: http://dx.doi.org/10.4038/sljch.v49i4.9288

(Key words: Paediatric COVID-19, BCG vaccination)

Dear Editor,

The association between COVID-19 and BCG vaccination is an interesting issue. It is proposed that BCG vaccination might be useful in reducing COVID-19 infection and mortality ${ }^{1}$ and that it might be a useful tool for COVID-19 containment. However, this issue is still a controversial one for discussion $^{2}$. A recent report from Sweden showed that $\mathrm{BCG}$ vaccination is useless for preventing COVID-19 among the paediatric population ${ }^{3}$. Here, the authors would like to share observation from Indochina where tuberculosis is highly prevalent and COVID-19 is still a common problem. Focusing on local official data, paediatric COVID-19 is usually mild and there are still no paediatric deaths ${ }^{4}$. All paediatric patients are under the national policies for mandatory BCG vaccination. Nevertheless, if the data in adults are considered, it is observed that there are still COVID-19 deaths among BCG vaccinated adults. Hence there is still no evidence that BCG vaccination can help prevent paediatric COVID-19 infection and deaths.

\section{References}

1. Jirjees FJ, Bashi YHD, Al-Obaidi HJ. COVID-19 death and BCG vaccination programs worldwide. Tuberculosis and Respiratory Diseases (Seoul) $2020 \mathrm{Sep} 4$. https://doi.org/10.4046/trd.2020.0063 PMid: 32883062
2. Maheshwari N, Jain A. Is there a rationale for using Bacillus Calmette-Guerin vaccine in coronavirus infection? Viral Immunology 2020 Aug 26.

https://doi.org/10.1089/vim.2020.0079

PMid: 32857679

3. de Chaisemartin C, de Chaisemartin L. BCG vaccination in infancy does not protect against COVID-19. Evidence from a natural experiment in Sweden. Clinical Infectious Diseases 2020 Aug 23. https://doi.org/10.1093/cid/ciaa1223 PMid: 32829400

4. Yasri S, Wiwanitkit V. Clinical features in paediatric COVID-19. Pediatric Pulmonology 2020; 55(5):1097. https://doi.org/10.1002/ppul.24737 PMid: 32196995 PMCid: PMC7167630

\footnotetext{
*Beuy Joob ${ }^{1}$, Viroj Wiwanitkit ${ }^{2}$

${ }^{1}$ Private Academic Consultant

${ }^{2}$ Honorary Professor, Dr. DY Patil University,

Pune, India

*Correspondence: beuyjoob@hotmail.com

(iD)

orcid.org/ 0000-0002-5281-0369
} 